Gut, 1972, 13, 654-657

\title{
Excitatory effects of adrenaline upon isolated preparations of human colon
}

\author{
D. J. GAGNON, G. DEVROEDE, AND S. BELISLE \\ From the Department of Pharmacology and the Gastrointestinal Research Unit, Centre Hospitalier \\ Universitaire, University of Sherbrooke, Sherbrooke, Quebec, Canada
}

SUMMARY The effect of beta-adrenergic blockade with oxprenolol upon adrenaline-induced relaxation of strips of human sigmoid colon was investigated.

Following blockade of beta-adrenoceptors with oxprenolol, adrenaline evoked dose-dependent contractions of both longitudinal and circular muscle strips. Storage of the tissues for periods up to 24 hours at $4^{\circ} \mathrm{C}$ did not modify the responses to adrenaline. Furthermore, the contractions induced by adrenaline following oxprenolol were significantly diminished by the addition of phentolamine, an alpha-adrenoceptor blocking agent.

Our results would suggest that oxprenolol has the property of unmasking or revealing alpha receptors responsible for the excitatory effects of adrenaline upon isolated strips of human colon.

The introduction of new beta-adrenergic blocking agents revealed stimulatory responses of different gastrointestinal tissues to catecholamines. Thus, the rat colon contracts when it is stimulated by adrenaline or noradrenaline following blockade of betaadrenergic receptors with pronethalol (Regoli and Vane, 1964); similar results were observed with human taeniae coli (Bucknell and Whitney, 1964). More recently, contractile responses of different segments of the guinea-pig gastrointestinal tract to catecholamines has been reported (Bailey, 1968; Guimaraes, 1969). We (Gagnon and Belisle, 1970) have clearly demonstrated that beta-blockade with oxprenolol reversed the relaxation of the rat isolated colon induced by adrenaline or noradrenaline into contraction; similar results were also reported (Belisle and Gagnon, 1971) with human and rabbit taeniae coli.

The purpose of the present investigation was to study systematically the effects of beta-blockade with oxprenolol on the responses induced by adrenaline upon longitudinal and circular muscles of the human colon.

\section{Materials and Methods}

Human sigmoid colons, freshly resected (one hr), were taken to the laboratory in cool oxygenated Krebs solution. Specimens were dissected away from Received for publication 15 May 1972. the lesion responsible for the resection in an area which appeared macroscopically normal, and no case of inflammatory bowel disease was included in the study.

Strips of longitudinal (Bucknell and Whitney, 1964) and circular (Fishlock and Parks, 1963) muscles of $3 \mathrm{~cm}$ long were mounted in an organ bath and immediately superfused with Krebs solution at $37^{\circ} \mathrm{C}$, at a rate of $10 \mathrm{ml} / \mathrm{minute}$. The solution was gassed continuously with $95 \% \mathrm{O}_{2}$ and $5 \% \mathrm{CO}_{2}$, and was composed of $(\mathrm{g} / 1): \mathrm{NaCl}, 6.9 ; \mathrm{KCl}, 0.35$; $\mathrm{CaCl}_{2}, 0.28 ; \mathrm{KH}_{2} \mathrm{PO}_{4}, 0 \cdot 16 ; \mathrm{MgSO}_{4} .7 \mathrm{H}_{2} \mathrm{O}, 0 \cdot 29$; dextrose, $2 ; \mathrm{NaHCO}_{3}, 2 \cdot 1$.

Superfusion was done in cascade (Gaddum, 1953). Solutions of agonists and antagonists were infused into the superfusing fluid at a rate of $0.1 \mathrm{ml} / \mathrm{min}$ for fixed periods of four minutes. The movements of the tissues were recorded isotonically with Harvard's no. 356 'heart and smooth muscle' transducers on an electronic Harvard recording system. The levers were counterweighted to exert $1 \cdot 5-2.0 \mathrm{~g}$ tension on the tissue. The changes of the baseline were calculated with a Keuffel and Esser planimeter, and the results expressed as the area below the tracing.

All specimens showed a variable spontaneous activity; on some occasions its amplitude was so important that it made the pharmacological investigation impossible. Those specimens which did not stabilize within the first 60 min were rejected. To study the effects of storage, the strips were stored in 
Krebs solutions, either at $4^{\circ} \mathrm{C}$ without oxygen or at room temperature $\left(23^{\circ} \mathrm{C}\right)$ with or without oxygen up to 36 hours.

Concentrations of drugs are expressed as final concentrations of the free bases in the superfusing fluid: $0.03,0.1,0.3$, and $1 \mu \mathrm{g} / \mathrm{ml}$ for adrenaline bitartrate, $10 \mu \mathrm{g} / \mathrm{ml}$ for oxprenolol $\mathrm{HCl}$, and $1 \mu \mathrm{g} / \mathrm{ml}$ for phentolamine mesylate. Solutions were freshly prepared in Krebs and adrenaline protected against oxidation by the addition of ascorbic acid. All experimental findings are expressed as means $\pm \mathrm{SE}$ and the differences between control and treatment periods were calculated according to an established method (Steel and Torrie, 1960).

\section{Results}

EFFECT OF ADRENALINE UPON LONGITUDINAL AND CIRC ULAR MU SCLE

A total of 52 strips obtained from seven patients were studied in two series of experiments. Strips of taeniae coli from the sigmoid colon relaxed to all doses of adrenaline and the degree of relaxation increased with increasing concentrations of adrenaline (Fig. 1). Following blockade of beta adrenergic receptors with oxprenolol, the relaxations of the strips normally induced by adrenaline were not only prevented but always reversed into dosedependent contractions (Fig. 1). However, our results also showed that the contractions induced by adrenaline were significantly diminished by the addition of phentolamine into the superfusing fluid; this was true for all doses of adrenaline (0.03, $\mathrm{P}<0.05 ; 0.1, \mathrm{P}<0.02 ; 0.3, \mathrm{P}<0.02 ;$ and $1 \mu \mathrm{g} / \mathrm{ml}$, $P<0.05)$.
Strips of circular muscle from the sigmoid region always relaxed to adrenaline and the responses were also shown to be dose-dependent. As in the case of longitudinal muscles, these relaxations were converted into contractions following beta-adrenergic blockade induced by the addition of oxprenolol into the superfusing medium (Fig. 1), and the amplitude of these contractions was proportional to the dose of adrenaline. On the other hand, the relaxations (before oxprenolol) and the contractions (after oxprenolol) induced by adrenaline upon circular muscles were much less important quantitatively than those induced by this same agent upon longitudinal muscles. This is why no attempt was made to prevent the contractions induced by adrenaline in this case.

\section{EFFECT OF TISSUE STORAGE}

Typical responses to adrenaline could be elicited after storage. Figure 2 shows the responses induced by adrenaline alone, with beta-adrenergic blockade and with alpha and beta blockade of adrenergic receptors, after a storage of 24 hours at $4^{\circ} \mathrm{C}$ of a strip of longitudinal muscle.

The most striking differences observed between normal and stored tissues resided in the fact that it took from 90 to $120 \mathrm{~min}$ for the spontaneous activity to develop fully and for the baseline to become stable with tissues stored at $4^{\circ} \mathrm{C}$ for periods of 24 hours. This period of storage did not modify the responses to adrenaline which induced relaxations comparable to those observed with normal tissues. Following beta-adrenergic blockade with oxprenolol, adrenaline contracted all strips, the stimulatory responses being similar to those ob-

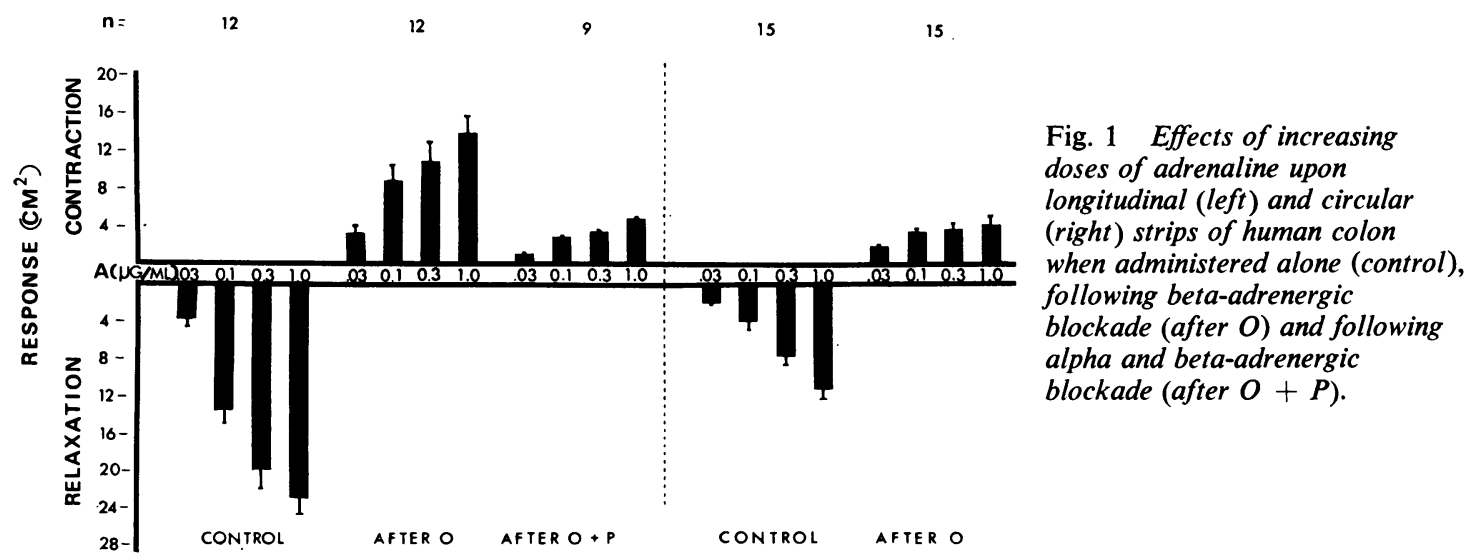

$A=A D R E N A L I N E$

$P=$ OXPRENOLOL

$n=$ NUMBER OF OBSERVATIONS

Fig. 1 Effects of increasing doses of adrenaline upon longitudinal (left) and circular (right) strips of human colon following beta-adrenergic blockade (after $O$ ) and following alpha and beta-adrenergic blockade (after $O+P$ ). 
$\begin{array}{llll}A(N G / M L) & 300 & 300 & 300\end{array}$

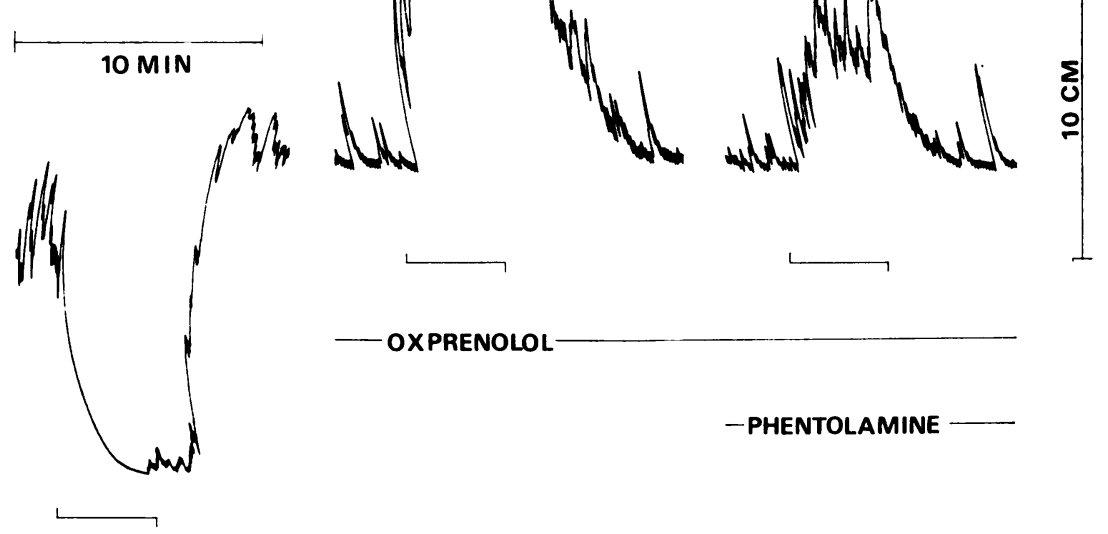

Fig. 2 Typical effects of a fixed dose of adrenaline (A) upon a longitudinal strip of human colon stored at $4^{\circ} \mathrm{C}$ for 24 hours. Oxprenolol converted the control relaxation (left) into a contraction (middle) which is greatly diminished by phentolamine. Horizontal bars indicate periods of infusion of adrenaline.

served with normal (not stored) tissues. The addition of phentolamine significantly diminished the contractile responses induced by all doses of adrenaline after oxprenolol (P $<0.05 ; \mathrm{P}<0.02 ; \mathrm{P}<0.02$; $P<0.05$, respectively).

Storage at $4^{\circ} \mathrm{C}$ for periods of 30 hours or more modified the responses to adrenaline which then induced either slight contractions $(0 \cdot 1$ and $0 \cdot 3 \mu \mathrm{g} / \mathrm{ml})$ or relaxation $(1 \mu \mathrm{g} / \mathrm{ml})$. After the addition of oxprenolol, adrenaline induced very slight contractions of the strips. These contractions were weaker than those induced in fresh tissues by the same treatment whether the concentration of adrenaline was 0.03 ( $P<0.01), 0.1(P<0.02), 0.3(P<0.01)$, or $1 \mu \mathrm{g} / \mathrm{ml}(\mathrm{P}<0.01)$.

Finally, specimens stored for 24 hours at room temperature with or without oxygen relaxed normally to adrenaline but the addition of oxprenolol converted the relaxations to only very weak contractions of lesser amplitude than in fresh tissues or tissues stored at $4^{\circ} \mathrm{C}$ for 24 hours. The effect of phentolamine was not studied in that case.

\section{Discussion}

The present study is not compatible with classical theories (Ahlquist and Levy, 1959) which suggests that both alpha and beta-adrenergic receptors should relax intestinal tissue. The fact that betaadrenergic blockade with oxprenolol not only prevented the inhibitory effect of adrenaline but transformed it into excitatory effects (contractions) confirms previous findings with isolated tissues of rat (Gagnon, and Belisle 1970; Belisle, and Gagnon, 1971) and guinea-pig (Bailey, 1968; Guimaraes, 1969). A similar observation was made with human tissue following propranolol (Bucknell and Whitney, 1964).

The discrepancy between our results and classical theories may be due to the type of beta-adrenergic blocking agent which was used. Hence, it has been shown that pronetholol and propranolol fulfil the conditions of competitive antagonism with sympathomimetic amines on both beta and alphaadrenergic receptors (Gulati, Gokhale, Parikh, Udmadia, and Krishramurty, 1968). We have also observed that following beta blockade with propranolol, adrenaline induced only slight contractions of the rat isolated colon (Gagnon and Belisle, 1970). Our results thus suggest that oxprenolol has the property of unmasking or revealing alpha receptors for catecholamines; in other words, 
it does not interfere with the action of catecholamines upon alpha receptors. Other studies (Hedges and Turner, 1971) have also shown that oxprenolol may possess an intrinsic sympathomimetic activity upon strips of detrussor bladder neck muscle and of stomach. Our studies with the human, rat, and rabbit colon have clearly demonstrated that at doses up to $50 \mu \mathrm{g} / \mathrm{ml}$, oxprenolol, like propranolol, invariably causes a relaxation of the tissue together with a slight decrease in spontaneous activity. On the other hand, we also observed that following doses of 100 $\mu \mathrm{g} / \mathrm{ml}$ and above oxprenolol may induce a contraction of the human and rat colon, but this effect can in no way be related to the reversal of adrenalineinduced relaxation into contraction. Furthermore, the adrenaline-induced relaxation of the colon isalso transformed into a contraction by other new betaadrenergic blocking agents (alprenolol and MK 950) which did not show any intrinsic contractile activity (Gagnon and Boucher, 1972).

Our results clearly show that following oxprenolol, adrenaline induced contractions of human colonic muscle which were reduced significantly by phentolamine, suggesting that these adrenaline-induced contractions are mediated through alpha receptors. Although we did not try further to characterize these responses with human specimens, a systematic study with rat isolated colons showed that the excitatory effects of sympathomimetic amines after beta-adrenergic blockade are not mediated through cholinergic or serotonergic mechanisms (Belisle and Gagnon, 1971; Gagnon, 1972). It seems reasonable to assume that human tissues do not differ from rat tissues in that matter. The hypothesis (Guimaraes, 1969) that two types of alpha-adrenergic receptors exist in gastrointestinal tissue of the guinea pig, one responsible for contraction and the other for relaxation, may thus also be applied to human longitudinal and circular colonic muscles.

Longitudinal muscle strips of human colon relaxed to a greater extent than circular strips. This may confirm previous findings (Hedges and Turner, 1969) of a larger population of beta-adrenoceptors in the longitudinal than in the circular muscle of the human colon.
The longer period of time required for the spontaneous activity to develop fully and stabilize following storage at $4^{\circ} \mathrm{C}$ for up to 24 hours does not constitute a major technical problem. Furthermore, these storage conditions do not influence tissue responses to adrenaline. Longer periods of storage or storage at room temperature influenced the response to adrenaline and, therefore, tissues should not be used when kept in these conditions.

The authors wish to thank Ciba Co Ltd (Montreal) for the supply of oxprenolol and phentolamine. This work was supported by a grant from the Medical Research Council of Canada.

\section{References}

Ahlquist, R. P., and Levy, B. (1959). Adrenergic receptive mechanism of canine ileum. J. Pharmacol. exp. Ther., 127, 146-149.

Bailey, D. M. (1968). Some effects of sympathomimetic amines on isolated smooth muscle preparations from the stomach of the guinea-pig. Brit. J. Pharmacol., 34, 204P.

Belisle, S., and Gagnon, D. J. (1971). Stimulating action of catecholamines on isolated preparations of the rat colon and human and rabbit taeniae coli. Brit. J. Pharmacol., 41, 361-366.

Bucknell, A., and Whitney, B. (1964). A preliminary investigation of the pharmacology of the human isolated taenia coli preparation. Brit. J. Pharmacol., 23, 164-175.

Fishlock, D. J., and Parks, A. G. (1963). A study of human colonic muscle in vitro, Brit. med. J., 2, 666-667.

Gaddum, J. H. (1953). The technique of superfusion. Brit. J. Pharmacol., 8, 321-326.

Gagnon, D. J. (1972). Contraction of the rat colon by sympathomimetic amines: Effect of methysergide and 5-HT desensitization. Europ. J. Pharmacol., 17, 319-324.

Gagnon, D. J., and Belisle, S. (1970). Stimulatory effects of catecholamines on the isolated rat colon after beta-adrenergic blockade with oxprenolol and propranolol. Europ.J.Pharmacol., 12, 303-309.

Gagnon, D. J., and Boucher, P. (1972). Contraction of the rat isolated colon by adrenaline. J. Pharm. Pharmacol., 24, 154-155.

Guimarăes, S. (1969). Alpha excitatory, alpha inhibitory and beta inhibitory adrenergic receptors in the guinea-pig stomach. Arch. int. Pharmacodyn., 179, 188-201.

Gulati, O. D., Gokhale, S. D., Parikh, H. M., Udwadia, B. P., and Krishnamurty, V. S. R. (1969). Evidence for a sympathetic alpha receptor blocking action of beta receptor blocking agents. J. Pharmacol. exp. Ther., 166, 35-43,

Hedges, A., and Turner, P. (1969). Beta-receptors in human isolated smooth muscle. Brit. J. Pharmacol., 37, 547P-548P.

Hedges, A., and Turner, P. (1971). Effect of five $\beta$-adrenoceptor antagonists on the effects of isoprenaline and acetylcholine on human isolated smooth muscle. Brit. J. Pharmacol., 41, 426-427P.

Regoli, D., and Vane, J. R. (1964). A sensitive method for the assay of angiotensin. Brit. J. Pharmacol., 23, 351-359.

Steel, R. G. D., and Torrie, J. H. (1960). Principles and Procedures of Statistics. McGraw Hill, New York, Toronto, London. 